Genetic Resources and Crop Evolution 41: 133-150, 1994.

(C) 1994 Kluwer Academic Publishers. Printed in the Netherlands.

\title{
The origin of Manihot esculenta Crantz (Euphorbiaceae)
}

\author{
Antonio C. Allem \\ CENARGEN/aEMBRAPA, Caixa Postal 02372, 70849-970, Brasilia, DF, Brazil
}

Received 7 October 1992; accepted 21 September 1993

Key words: Manihot, cassava, origin, South America, infraspecific taxonomy

\begin{abstract}
Summary
Contrary to views that cassava (Manihot esculenta) is only known in cultivation an argument is made that wild accessions of the species grow over much of the American neotropics, in Brazil, Bolivia, Peru, Venezuela, Guyana, and Surinam. Three subspecies are recognized. $M$. esculenta subsp. esculenta is the domesticate and includes all cultivars known in cultivation. The wild $M$. esculenta subsp. peruviana occurs in eastern Peru and western Brazil. The wild $M$. esculenta subsp. flabellifolia shows a wider distribution and ranges from the central Brazilian state of Goiás northward to Venezuelan Amazonia. The large area of distribution of the two wild subspecies makes it difficult to assign a place of initial domestication.
\end{abstract}

\section{Introduction}

Reviews on the origin of New World crops (Smith, 1968, 1977; Pickersgill, 1977; León, 1977; Pickersgill \& Heiser, 1977; Heiser, 1979) acknowledge that little is known on the ancestry of cassava. Papers dealing with the origins of important American crops such as beans (Gentry, 1969; Kaplan, 1971), the groundnut (Gregory et al., 1980), maize (Beadle, 1977), and potatoes (Hawkes, 1979) have further highlighted the fact that, of all major tropical crops, the origin of cassava has remained the least understood.

Baker's (1971: 441) classic remark set the tone for the current research: "in the case of the South American cucurbits, it looks as if we are up against a familiar problem. Why is it that the ancestors of domesticated plants are now so rare (or even extinct)? It is hard to see how domestication of Cucurbita would make life any more difficult for the wild species". Besides, during a workshop on cassava at the International Institute of Tropical Agriculture in Ibadan, Nigeria, December 1982, Dr S. K. Hahn suggested that the time was ripe for the renewed quest of the origin of the root crop.

EMBRAPA's collection of germplasm of wild species of Manihot started in 1976. The first time CENARGEN's collecting team found what seemed to be wild forms of cassava took place near the town of Iporá, $1625 \mathrm{~S} 5104 \mathrm{~W}$, state of Goiás, in March 1982. The population (Allem, Vieira and Werneck 2794) was thriving on a rocky outcrop. Despite the fair evidence of a wild habitat, the finding was temporarily regarded as feral cassava. Small wonder, for there persisted the belief that wild forms of cassava no longer existed.

The author decided to further investigate the subject. The results revealed that cassava is as wild as any other species of the genus Manihot (Allem, 1987).

\section{Materials and methods}

Live populations of wild $M$. esculenta were sampled and documented in Brazil in 1986 and 1992. An initial account is given in Allem (1987). Voucher specimens of the two wild strains of 
cassava collected in tropical Brazil were shared with North American and West European herbaria (Appendices 1 and 3).

Cassava's lectotype, i.e. Merian's (1705) figures 4 and 5 , was examined by the author while at Kew in 1984. An isotype of $M$. peruviana was examined at the Museum of Natural History in Paris in 1981. Syntypes of $M$. flabellifolia were examined while working at the Department of Botany, Plant Science Laboratories, The University of Reading, in 1984.

The taxonomic conclusions reached in this study were mainly the result of comparative morphological studies involving all the species concerned. In a few cases (e.g. $M$. orinocensis), the reduction to the synonymy concurred with literature accounts.

The section "the literature on the wild ancestors of cassava" gives an account on how the rationale was developed by the author leading to the taxonomic classification in the $M$. esculenta complex herein proposed.

Authors' names related with the $M$. esculenta complex, i.e. Manihot sect. Manihot, appear in the taxonomic treatment at the end of the paper.

The maps were plotted using a geographic information system (GIS) software PC-Arc/Info.

The curators of the following herbaria kindly assisted with the loans of specimens. Acronyms of herbaria follow Holmgren et al. (1990), Index Herbariorum, ed. 8: Centro Nacional de Recursos Genéticos, CENARGEN-EMBRAPA, Brasília, Brasil (CEN); Dept. of Botany, University of California, Davis (DAV); Conservatoire et Jardins Botaniques, Geneva, Switzerland (G); Instituto Agronômico do Norte, CPATU-EMBRAPA, Belem, Brasil (IAN); the Herbarium, Royal Botanic Gardens, Kew (K); Museu Paraense Emilio Goeldi, Belém, Brasil (MG); Missouri Botanical Garden, St. Louis, Missouri (MO); United States National Arboretum, Washington, D.C. (NA); New York Botanical Garden, Bronx, New York (NY); Laboratoire de Phanérogamie, Museum National d'Histoire Naturelle, Paris, France (P); Jardim Botânico, Rio de Janeiro (RB); Naturhistoriska Riksmuseum, Botanical department, Stockholm, Sweden (S); Botanical Museum and Herbarium, Utrecht, The Netherlands (U); U.S. National Herbarium, Smithsonian, Washington, D.C. (US); Naturhistorisches Museum, Vienna, Austria (W).

\section{Views on the origin of cassava}

Early writers dealing with the origin of cassava (e.g., Pohl, 1827; Mueller, 1874; Pax, 1910) concentrated on the place of origin of the food crop and neglected its botanical relationships.

A determined effort to track down the origin of cassava began with Rogers' publications in the 1960 s and early 1970s. In his papers on the subject (Rogers, 1963, 1965, 1972; Rogers \& Fleming, 1973; Rogers \& Appan, 1973) he consistently stated that cultivars of $M$. esculenta had hybridized with other locally occurring native species to form complexes. The great variability thus found to exist within the domesticate expressed the end result of such multiple and random introgressions. In his final work on the genus (Rogers \& Appan, 1973: 1) it is stated that so great a variation within the cultigen "must be attributed to hybridization". Renvoize (1972) also suggested that wild weedy species of Manihot from northeastern Brazil may have descended from feral cassava. The author disagrees with such views.

\section{Wild populations of Manihot esculenta}

During a field trip to the state of Mato Grosso in 1985, Dr José Valls collected specimens and seeds of a species which he and the field technician Glocimar P. da Silva described to this author as so close morphologically to cultivated cassava as to practically preclude separation on morphological grounds. They were sure of the wild status of the population, with dozens of individuals spreading in the bushwood along the roadside of the Indian reservation known as Guaporé.

On the basis of this information a special trip was made to the Brazilian states of Goiás, Mato Grosso, and Rondônia in May 1986. The trek was highly successful and several wild populations of $M$. esculenta were found in all three states. The stoutest specimens, climbing woody forms up to $8 \mathrm{~m}$ high, were mainly confined to the states of Mato Grosso and Rondônia. A short account of these results was published a year later (Allem, 1987).

The author tried to document undomesticated populations of cassava with as many botanical 


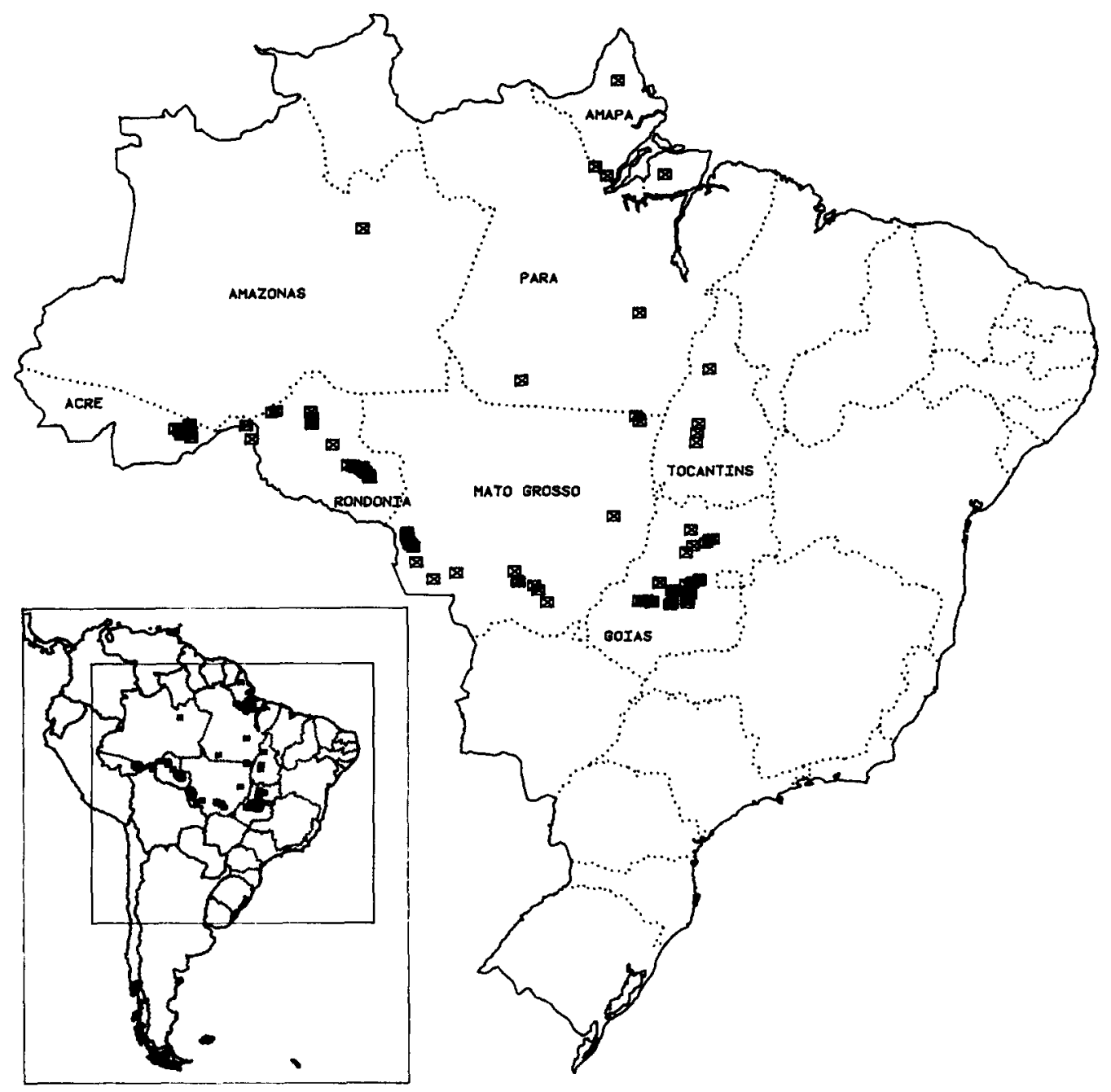

Fig. I. Distribution of M. esculenta subsp. flabellifolia in Brazil. See Appendix 1.

collections as possible'. Brazilian material from over seventy sites, mainly from Goiás, Mato Grosso, Rondônia, and Acre (Figs. 1-3) was personally amassed by him. A representative set of duplicates was forwarded to a number of North American and West European herbaria in August 1988 (Appendices 1 and 3).

\footnotetext{
1 Two recent reports (Bretting, 1990; Heiser, 1990) suggest that the author may be mistaken and took feral cassava for wild species. The historiography here presented makes ciear this is not the case. Besides, there is the recent announcement (Allem, 1992) that $M$. flabellifolia and $M$. peruviana were found inside non-converted forests from the states of Goiás and Mato Grosso.
}

The two wild strains of cassava collected in the 1986 and 1992 missions are discussed in more detail in the next two sections.

\section{The wild species Manihot fabellifolia}

Pohl's (1827) treatment provided the basic framework for the taxonomic classification of cassava. Pohl's $M$. flabellifolia was collected around the municipality of Jaraguá, $1548 \mathrm{~S} 4915 \mathrm{~W}$, in the state of Goiás. His remarks about this species ("habitat in sylvis inter frutices, ad margines viarum circa Corgo do Jaragua in sylva Mato Grosso dicta") and $M$. digitiformis ("habitat inter 


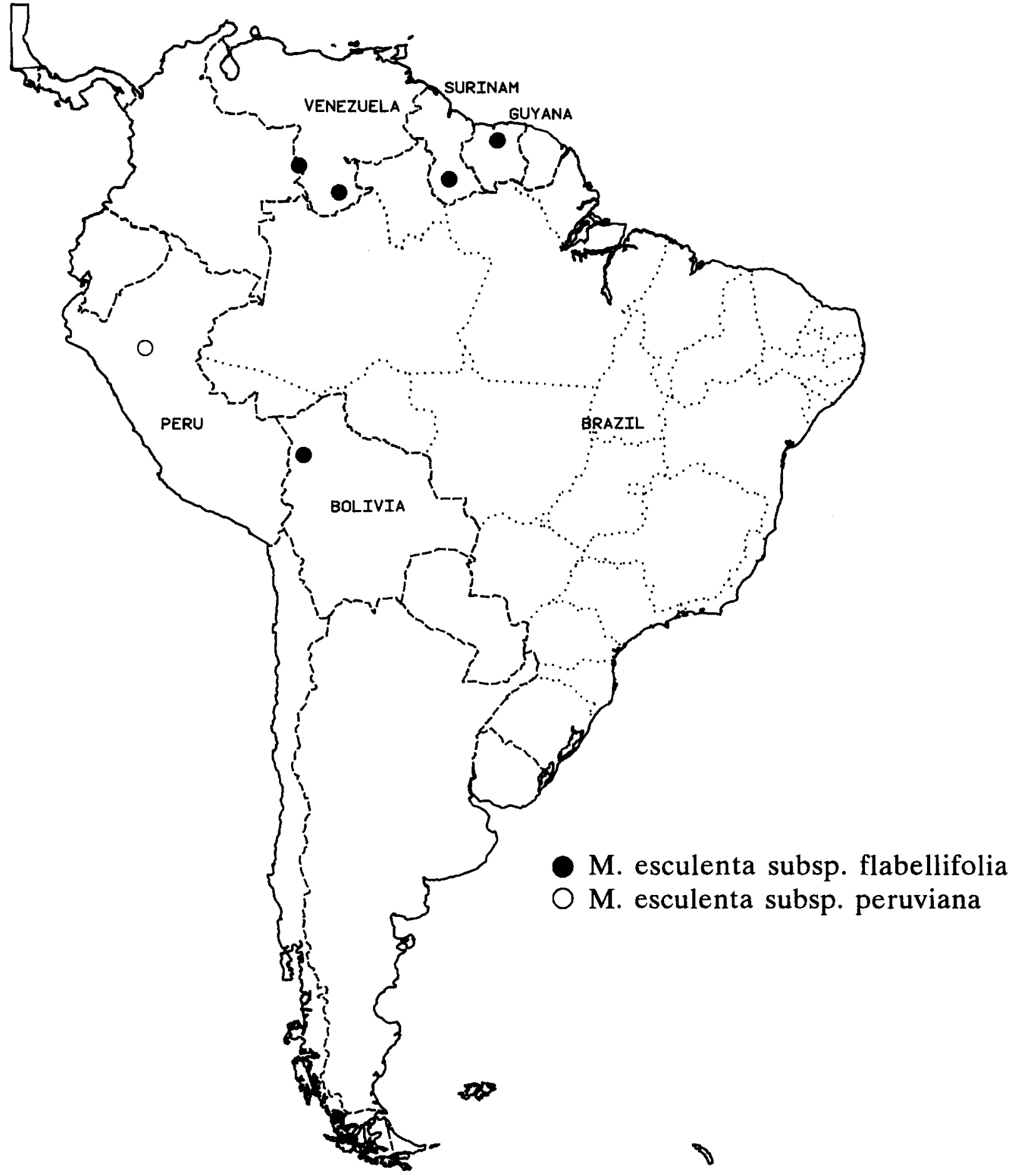

Fig. 2. Distribution of the two wild subspecies of cassava in South America (except Brazil). See Appendix 2. 


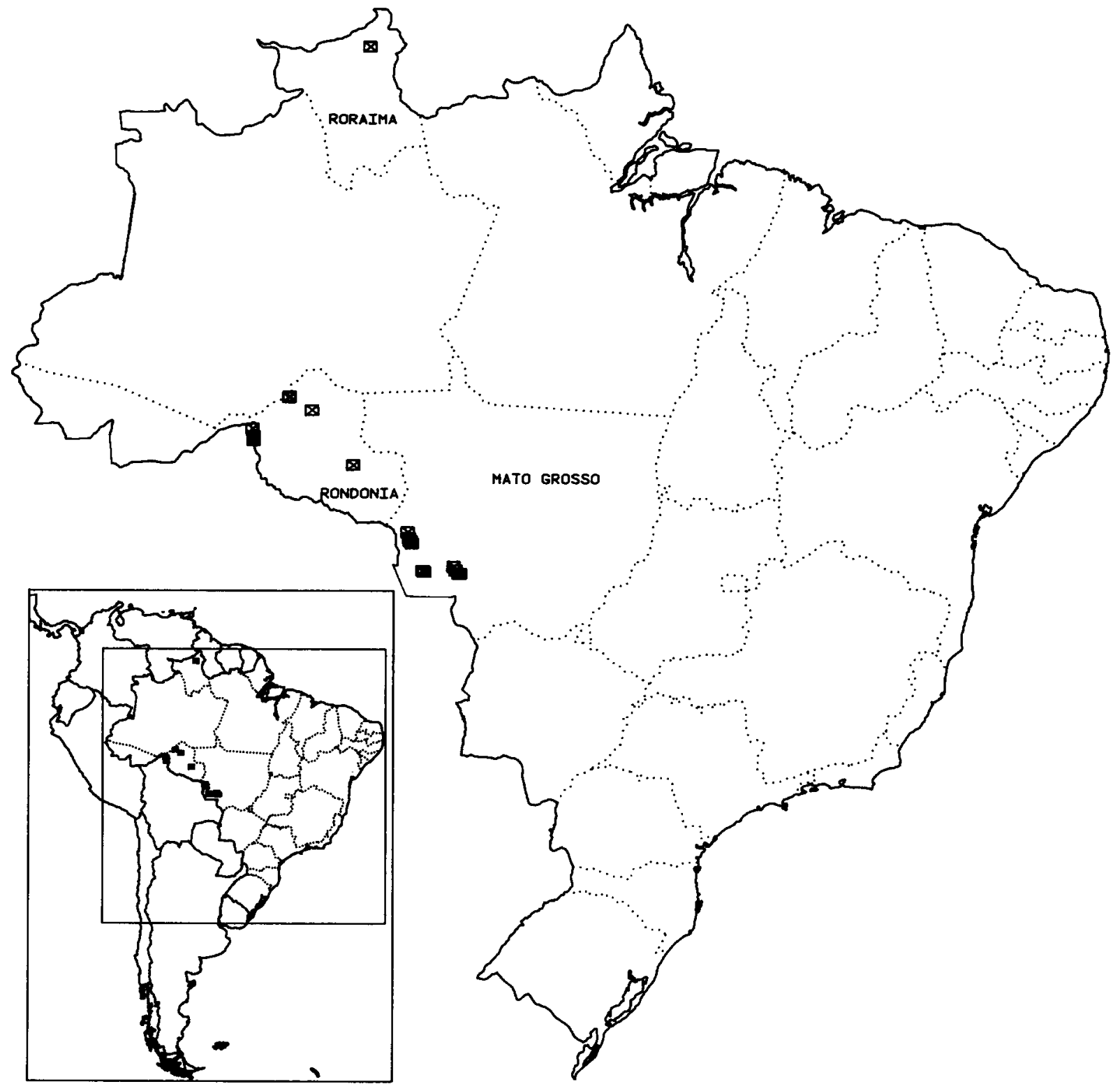

Fig. 3. Distribution of $M$. esculenta subsp. peruviana in Brazil. See Appendix 3.

frutices et dumeta, ad Corallinho") leave little doubt that he was referring to wild material, particularly when one confronts these remarks with those he made for $M$. utilissima and $M$. aipi in the same work. Both Mueller (1874) and Pax (1910) followed Pohl in his treatment of the two species as wild native taxa. Rogers \& Appan (1973) put the two under the synonymy of the cultigen.

The author has been searching for $M$. flabellifolia around the nearby municipalities of Jaraguá,
Corumbá de Goiás, and Pirenópolis, in the state of Goiás, since 1986. Pohl had been touring these places in the years of 1819 and 1820. Agriculture has replaced most of the original vegetation of the area since then. The remnant vegetation is a type of dry semicaducifolious forest often referred to as Cerradão. The author succeeded in locating half a dozen wild sites near these three small towns where $M$. flabellifolia can still be found nowadays. 
On 9 December 1986 the team located a wellpreserved site with a small population of $M$. flabellifolia thriving about $3.2 \mathrm{~km} \mathrm{SE}$ of the town of Pirenópolis, $1552 \mathrm{~S}, 4900 \mathrm{~W}$, and less than $15 \mathrm{~km}$ from the outskirts of the nearby town of Corumbá de Goiás. The habitat was an islet of woods of ca. $800 \mathrm{~m} \times 500 \mathrm{~m}$. The woodland was semivirgin, non-converted, dry Cerradão forest. The site was revisited on 30 May 1993 and the administrator $\mathrm{Mr}$ Luiz told the team that the property had been bought by Dr Creone, a physician from Goiânia, in 1982. Large tracts of the estate had virgin forest at that time and the owner decided to convert part of the property into farmland and preserve that part of the woods. The administrator said that some logging had taken place until a few years ago in small patches of the refuge but that it had stopped nowadays. Additional evidence of the wild status of the site is given by the density of the vegetation and the presence of trees up to $20 \mathrm{~m}$ high.

The author considered the name $M$. digitiformis to represent the glabrous wild subspecies of $M$. esculenta at the expense of the name $M$. flabellifolia. He saw both types deposited in the Naturhistorisches Museum (W) and $M$. digitiformis has much richer flowering material in the sheets. $\mathrm{Ci}$ ferri's (1942) fortuitous choice in favouring $M$. flabellifolia, however, cannot be overruled.

The section 'the taxonomy of cassava', at the end of the paper, lists eight species under the synonymy of subsp. flabellifolia. Part of the arguments used to support that viewpoint have been discussed earlier in the text. In questionable cases, the author had no other option but to turn to rational deduction to effect the move. For example, the case of $M$. orinocensis. The only known specimen of this species was collected by Williams in Venezuelan Amazonia. The material from the herbarium of Stockholm (S) has just a few leaves. Croizat (1943a: 169) frankly admitted that the "type specimen is hardly better than a scrap", possessing only a few leaves and a handful of male flowers. Rogers \& Appan (1973) regarded $M$. orinocensis as a synonym of $M$. tristis. Their decision is probably right, and is followed in this study. Likewise, the isotype specimens of $M$. tristis (Spruce 3604) deposited in geneva (G) and Vienna (W) possess only a few leaves and a single decayed fruit. Fortunately, isotypes with fruits in better state of conservation were found in Paris (P). This helped to strengthen the author's conviction in this particular case.

Some of the other erstwhile species under scrutiny in this study (e.g., M. utilissima or the native $M$. flexuosa from Bahia) are, in general, poorly represented in herbaria, lacking important parts such as floral bracts, fruits and seeds, not collected at the original sites or lost with the passage of time.

Herbarium material of $M$. flabellifolia and $M$. digitiformis deposited in Vienna (W) is nearly complete. Both are remarkably uniform in their floral morphologies with highly branched panicles, minute and early deciduous floral bracts, lengthy filiform male pedicels, winged fruits, cylindrical seeds etc, like that known in cultivated cassava. Pohl's specimens are complete from a botanical standpoint but nonetheless still leave a little to be desired from a taxonomic viewpoint. The fruits are, for the most part, young which prevents a thorough assessment of the shape and size of the seed. In the same way, Lanjouw's (1939) M. saxicola is poorly illustrated in the original. The line drawing is insufficient in details to permit an association beyond reasonable doubt that it belongs to the complex. The author examined three specimens of the species deposited at Utrecht (U). None showed fruits, only male flowers are present.

\section{The wild species Manihot peruviana}

The first time CENARGEN's collecting team found $M$. peruviana was in May 1986 , in the states of Mato Grosso and Rondônia. In northern Mato Grosso, near the municipality of Pontes e Lacerda, $1538 \mathrm{~S} 5848 \mathrm{~W}$, the team found magnificent specimens matching notably well with the vegetative and floral morphology of cultivated cassava. The specimens were mostly woody shrubs to treelets up to $4 \mathrm{~m}$ in height. Climbing individuals twisting around other trees reached up to $8 \mathrm{~m}$ in height. Some specimens (e.g., Allem \& Werneck 3534) locally formed dense meshes, with anastomosing stems and intertwined branches, that prevented entry.

As a rule, all parts of the specimens of Mato Grosso were pubescent, but often became glabrescent with age. Pubescence of the winged fruits was 
easier to note in younger phases of the development, ripe fruits often were glabrescent, with sparse hairs. Moreover, the collection Allem, Bonierbale and Hahn 4121 from Pontes e Lacerda, 8 June 1993, shows a pubescent plant, but quite a few ovaries are glabrous while others are sparse pubescent. All ripe fruits were glabrous. The situation recurred with numbers 4132 and 4141 , this time in the state of Rondônia.

The specimens collected in the state of Rondônia, particularly those found along highway BR-364 leading to the neighbouring state of Acre, were shrubs of moderate size, $2-3 \mathrm{~m}$ in height. The indumentum on stems and leaves was more dense and conspicuous than in Mato Grosso because of the shaggy aspect of the hairs. Ripe fruits were usually covered with showy hirsute hairs, but see the remarks above.

The most spectacular discovery of $M$. peruviana was in the municipality of Lambari (15 26 S 57 $52 \mathrm{~W}$ ), state of Mato Grosso, on 9 June, 1992. The author spotted half a dozen individuals thriving inside the virgin forest. They stood ca. 6 metres from the edge of the forest and, upon entering the woods, the habit was that of subscandent, woody, vine-like shrubs, clambering over other vegetation, with branches to $7 \mathrm{~m}$ long. The virgin forest is being converted into sugar cane plantations at the time of writing (June, 1992) and an account and illustrations of this most rare discovery are found in Allem (1992).

The recognition of this taxon as a subspecies of $M$. esculenta has somewhat to do with geography and morphology. The taxon is more or less confined to a restricted area, eastern Peru and westernmost Brazilian states of Mato Grosso and Rondônia. A disjunct population (M. surumuensis) is found in the far northern Brazilian state of Roraima. Besides, the tomentose vestiture of $M$. peruviana makes it a conspicuous morph within the multitude of forms in the gene pool of the root crop. Of course, moderate vestiture on the leaves of some cultivars of $M$. esculenta has long been known, but in $M$. peruviana the hairs also cover other parts of the plant. Of distinctive importance is the hirsute vestiture on the rachis of the inflorescence, floral bracts, male pedicel, flowers and fruits.

The author saw the type specimen of $M$. peruviana deposited at the Museum of Natural History
(P) in Paris in October 1981. For him, there was no way to tell this species apart from the pubescent material now found in Brazil's northwesternmost states. Rogers \& Appan (1973: 197) described the fruit of $M$. peruviana with "surface smooth" but, certainly, this is a mistake. The nearly ripe fruits of the type specimen (Spruce 4287) in Paris unequivocally show strongly developed wings.

The taxonomy of subsp. peruviana leaves room for further improvement. In the section 'the taxonomy of cassava', $M$. surumuensis is placed under its synonymy. However, the material at hand is inadequate and the final classification of this species will have to wait for additional collections from the original area.

\section{The literature on the wild ancestors of cassava}

Three authors, Lanjouw, Bolhuis and Jennings played a key role in drawing attention to the existence of putative wild progenitors of cassava. The latter two, benefitting from Nichol's (1947) pioneer observation on the subject, not only called attention to the unique biosystematic results obtained with these wild strains but also commented upon the taxonomic relationship existing between the cultigen and the tested wild species in Africa and Asia.

Lanjouw (1935) excused himself for placing under $M$. esculenta in his 1931 study of the Euphorbiaceae of Surinam, material that ought clearly to be regarded as distinct from the cultigen. At the time he was sure of the distinction of the material after collecting it personally during a short special trip to the collection site in 1933: "a description of this species will follow at a later date ...; probably this species is the original form of $M$. esculenta, which is only known as cultivated" (p. 238). In a subsequent paper Lanjouw (1939) described the new species as $M$. saxicola, giving some relevant comments on the saga of cassava. After going to the Voltzberg, a low mountain seemingly close to Paramaribo, he returned with flowering material and germplasm of the new species. He remarked (1939: 544) about the newlycreated $M$. saxicola that "perhaps this new species may be regarded as the ancestor of the $M$. esculenta Crantz, which is known as a cultivated plant only". Lanjouw noted that the new species closely 
resembled $M$. melanobasis described from British Guyana. His description of the fruit of $M$. saxicola ("capsula minute 6-alata, alis undulatis", p. 546) could have suggested to authors a wild form of cassava, for winged fruit is typical of the domesticate. In the monograph (Rogers \& Appan, 1973), $M$. saxicola was placed under $M$. tristis (another member of the complex). Lanjouw (1939: 549) made a short comment about the find of $M$. melanobasis in the savanna of the upper Sipaliwini river in Surinam by E. H. Rombouts in 1936 . He said this was a rare species and then proceeded to complement Johannes Mueller of Aargau's original description by making use of the specimens Rombouts 409 and Rombouts 464: "capsule ca. $11 \mathrm{~mm}$ in height ca. $9 \mathrm{~mm}$ in diametre, oblong, narrowly 6-winged." This was an important remark to call attention to the common morphological, ecological, and geographical background of $M$. saxicola and $M$. melanobasis. Lanjouw left no doubt about the winged fruit morphology of both taxa. In the monograph, Rogers and Appan placed $M$. melanobasis under the synonymy of $M$. esculenta, in spite of the place of collection annotated as "in Guiana anglica in savanna prope Pirara"see in this connection Mueller (1865) $)^{2}$. Moreover, the collection Rombouts 464 served as the type specimen of Rogers and Appan's newly-created $M$. surinamensis, another member of the complex, as debated below. The author saw the type specimen of $M$. surinamensis (Rombouts 464) and its fruit is characteristically winged. Rogers \& Appan (1973: 82), though, describe this species "fruits non vidi". They inspected the holotype deposited at Utrecht

2 David Rogers regarded all accessions morphologically resembling the cultigen as cultivated material, no matter what the labels said. $M$. melanobasis and $M$. saxicola, for example, come from savannas of British Guyana and Surinam but, like with other species, the data were not taken into due account. His view on the subject is self-evident: "many of the species epithets applied to $M$. esculenta are mere nomenclatorial synonyms, but several are here placed in synonymy for the first time, because we employ a broader concept of the species than any previous students. Thus, $M$. flabellifolia Pohl, $M$. flabellifolia Pohl, $M$. digitiformis Pohl, $M$. diffusa Pohl, $M$. loureirii Pohl, $M$. melanobasis Muell. Arg., M. sprucei Pax, and $M$. flexuosa Pax, all represent variations which fit well within our concept of this species. It is likely that each of the above species names is based upon materials collected from plants not consciously grown for their roots, but come from "volunteer" plants, apparently "wild" (Rogers \& Appan, 1973: 33).
(U) but perhaps did not notice that inside the envelope, at the bottom of the sheet, there were two nearly ripe fairly winged fruits.

Bolhuis (1953: 109) was the next to draw attention to the status of $M$. saxicola. After crossing this species with cultivated cassava he remarked that "the highly satisfactory results obtained even raised doubt if Manihot saxicola could be regarded as a new species". In a later paper (Bolhuis, 1967: 85), he again stressed the unique phenomenon of the cross between the cultigen and the Surinamese species: "particularly striking is the high percentage of success which is far in excess of the percentage found in crosses within the species $M$. utilissima. It makes it even questionable as to whether $M$. saxicola is sufficiently different from M. utilissima to consider it as a separate species, since both crosses have such a high percentage of success".

Even more enlightening remarks on the subject were those made by Derek Jennings. In his paper of 1959, he said that all East-African material of $M$. melanobasis originated in Surinam (it was probably part of the same stock the Dutch had sent to Indonesia under the name $M$. saxicola). He noted that the cross between cultivated cassava and $M$. melanobasis had resulted in a seed set greater than that obtained in intervarietal crosses just involving material from the root crop. Jennings' (1959: 161) statement, very important for the historiography of cassava, vindicates full quotation: "In view of the readiness with which the two species intercross, however, it is doubtful whether their separation as distinct species is justified. Bolhuis reached the same conclusion for $M$. saxicola and cassava, which also intercross very easily. Lanjouw noted that $M$. melanobasis has much in common with $M$. saxicola; he suggested that the latter species may be an ancestor of cassava which is only known as a cultivated plant. It appears from the data presented here that $M$. melanobasis could also be a closely related ancestor of cultivated cassava". Such a compelling statement was ignored by taxonomists of Manihot. His last statement on the subject (Jennings, 1963: 69, 75), again rich in thought-provoking arguments, passed in the same way unnoticed: "two wild forms of Manihot-M. saxicola and $M$. melanobasis-have been shown to be so closely related to cassava that their separation as distinct species cannot be 
justified" (and) "its ( $M$. melanobasis) relationship with cassava should clearly be regarded as subspecific". Later on, he changed his mind (Jennings, 1979) and took sides with Rogers \& Appan (1973) who regarded the North American $M$. aesculifolia (H.B.K.) Pohl, $M$. rubricaulis Johnston, and $M$. pringlei Watson as cassava's closest wild relatives.

Another meaningful communication was provided by Pax (1910) with his $M$. sprucei. This name was given as a footnote in Pax's (1910: 70) monograph. An abbreviated translation of Pax's diagnosis follows. "Note; the following specimen, collected by Spruce in the vicinities of Santarém, in the Brazilian state of pará, is certainly close to Pohl's $M$. digitiformis; it is very likely to be regarded as a new species: $M$. sprucei Pax ad int". The type specimen of $M$. spruce i is Spruce 825. The isotype the present author saw at the Museum of Natural History (P) in Paris, bearing the name Drake 825, Santarem, April 1850, is indistinguishable on morphological grounds from cultivated $M$. esculenta. The label, though, makes no mention of the plant being cultivated and most probably it was not. In fact, it is certain that wild $M$. esculenta ranges that far (Appendix 1 and Fig. 1). Pax certainly had no reservations about the wild status of the specimen and described it as new. Lanjouw (1932) decided to reduce $M$. sprucei to a variety of cultivated $M$. esculenta (actually, the original nomenclatorial combination had earlier appeared in his 1931 study of the Euphorbiaceae of Surinam) while Rogers \& Appan (1973) placed it under the synonymy of cassava without further distinction.

There are other communications concerned with the taxonomy of cassava. Coursey \& Booth (1977) recalled that $M$. melanobasis and $M$. saxicola ought to be regarded as the precursors of cassava but did not change nomenclature. Earlier on, Pax (1914) remarked that Huber had drawn attention to the fact that his $M$. marajoara, from the island of Marajó in northern Brazil, $0050 \mathrm{~W}$, resembled $M$. melanobasis from British Guyana. In turn, Croizat (1943a) described $M$. orinocensis from Puerto Ayacucho, in the Venezuelan Amazonia, on the basis of a single poorly preserved and very incomplete specimen collected by L. Williams. He pointed out its close kinship to Lanjouw's $M$. saxicola. It is possible that Croizat himself collected wild native $M$. esculenta; his single collection of Manihot in Puerto Ayacucho in 1951 is still undetermined
(Holst \& Todzia, 1990). In the monograph of 1973, Rogers and Appan placed $M$. orinocensis under the synonymy of $M$. tristis, which turned out, in this study, to be another member of the $M$. esculenta complex.

Investigators that crossed cultivated cassava with wild conspecific strains unanimously recorded satisfactory results. Their objectives dealt with both biosystematics (experimental taxonomy) and plant breeding. These studies provided data to reconstruct the phylogeny of the root crop, and a biological species concept for the $M$. esculenta complex (Baker, 1970) might be suitable. The assumption was strengthened with the use of wild strains of $M$. esculenta and other wild species of Manihot in the crosses. Alien alleles were passed on to the cassava genome. Analysis of its genome may throw authoritative light on the phylogeny and percentages of gene contribution from other species. In retrospect, cassava is no longer only a cultigen. It is better served with the term indigen, i.e. "a biological species that is known from both wild and cultivated forms" (Webster's Dictionary).

\section{History of the taxonomy of cassava}

Pre-Linnaean classification of cassava started with J. Bauhin's 'Historia Plantarum Universalis' of 1651. He studied material collected by André Thevet in Brazil and honored him naming the euphorbiaceous crop Manihot theveti (Rogers \& Appan, 1973). Linnaeus (1753: 1007) placed the crop in the related genus Jatropha, naming it $J$. manihot L. Linnaeus did not cite any specimen which might be designated as the type. In his later work, Linnaeus (1771: 497) still had not referred to a specimen. Miller (1754) provided the first valid diagnosis of the genus Manihot but did not refer to any specimen. He maintained $M$. theveti. J. F. Gmelin's 'Onamatologia Botanica Completa' of 1773 , vol. 5 , p. 7 , designated sweet cassava with the binomium Jatropha dulcis Gmelin which revealed itself a nomen nudum.

Crantz (1766), as pointed out by Rogers \& Appan (1973), provided the first post-Linnaean validly published name of the crop. Crantz (1766: 167) described cassava in the following economic way: "Manihot esculenta; Manihot foliis palmatis; lobis lanceolatis integerrimis laevibus. Manihot 
theveti etc. Mer. Surin. 4. f. 4 et 5." On the basis of Crantz's allusion to these two plates of Merian's (1705) work, Rogers \& Appan (1973) selected both as lectotypes of $M$. esculenta. They dated Merian's work to 1726 , but this was the third edition of the folio work (Stearn, 1982). The first (1705) edition of this work came out in Dutch and Latin versions.

Merian's (1705) 'Metamorphosis Insectorum Surinamensium' folio work depicts two illustrations of cassava. Her water-colour plate 4 depicts a wholly glabrous sterile individual of cassava bearing tuberous roots, green leaves and red petioles; a lizard and a butterfly are perched on the branches of the plant. Plate 5 shows an identical individual, except for the fact that this time a snake, a moth, an insect's larva, and a chrysalis are perched or twisted on the branches. A small cicad specimen also appears at one side of this plate. Stearn (1982) guesses she did all paintings while visiting the gardens around Paramaribo, between 1699 and 1701. From this faint historical record it can at best be assumed that Merian had drawn cultivated cassava growing in or around Paramaribo.

Croizat (1943b: 214) claimed that the name $M$. esculenta has little scientific meaning since the typification of the species rests on two plates showing sterile plants. Since cassava is so variable at the vegetative level Croizat concluded that it would perhaps be more appropriate to regard $M$. esculenta as a nomen ambiguum and, as a result, to propose a novel binomial for the species. Croizat's rationale relates all known morphs of cultivated cassava to Merian's plates.

Pohl's (1827) work affected in a decisive way the taxonomy of cassava. He had personally collected in central Brazil from 1817 to 1821 (Stafleu \& Cowan, 1983). On the basis of his own specimens he created two species to encompass the cultigen. One was $M$. utilissima for bitter cassava with high concentration of HCN. The other was $M$. aipi for sweet cassava with low concentration of $\mathrm{HCN}$. As regards these two species it is beyond dispute that Pohl was consciously referring to cultivated plants for he provided a lengthy economic discussion about them at the end of each description. He was certainly aware of the existence of Crantz's $M$. esculenta, which he placed under the synonymy of his newly-created $M$. utilissima. Pohl's procedure was later followed by Pax (1910). Pohl's M. utilis- sima became the standard binomial of the domesticate for a century, a trend much increased after Pax (1910) monographed the genus.

The Italian Raffaele Ciferri (1938) was the first to acknowledge the priority of Crantz's name $M$. esculenta. Ciferri had worked for some years as an agronomist in an experimental station in the Dominican Republic in the 1930s. He proposed an agronomic classification from material raised in the Dominican Republic and Haiti, whereby three major races were identified within the species. In a following paper of 1942, Ciferri aimed at settling nomenclatorial problems raised by his earlier classification. Following Pohl (1827), Mueller (1866, 1874), and Pax (1910), he set up an infraspecific classification for the species. Ciferri did not see types or any other collections of wild species of Manihot. He worked on the basis of descriptions and, whenever applicable, line drawings of the species concerned. A condensed original summary of his 1942 classification follows.

1A. M. esculenta Crantz subsp. esculenta

1B. leaf-lobes linear or linear sublanceolate up to filiform; scars on stems conspicuously raised, densely packed; roots elongate, cylindrical ... M. esculenta Crantz subsp. flabellifolia (Pohl) Ciferri

1C. leaf-lobes subovate or rotundate-lanceolate; scars on stem little raised, highly spaced; roots elongate, spheroidal or short-conical ...M. esculenta Crantz subsp. grandifolia Ciferri

Ciferri's $M$. esculenta subsp. grandifolia was provided with a Latin diagnosis but he did not cite any specimen as the type. He also did not keep vouchers of his new taxon.

Ciferri's (1942) M. esculenta subsp. flabellifolia is an enlightening case for analysis. M. flabellifolia, the basionym, is typified by the Brazilian collection Pohl 1188. While browsing through the monographs of Manihot, Ciferri was apparently looking for other species with narrow leaf-lobes that he regarded as conspecific with cassava. All synonyms he placed under subsp. flabellifolia (e.g., the Brazilian $M$. gracilis Pohl) belong to species having this particular leaf morphology. The irony is that $\mathrm{Ci}^{-}$ ferri created a name valid under the nomenclatorial rules which was improperly applied, i.e. Pohl's (1827) $M$. flabellifolia is a wild native representative of cassava and does not belong to the 
cultivated complex as thought by him. Ciferri, obviously unaware of such a subtlety, used the name to cover for a specific morph of the cultigen. Ciferri mistakenly conceived $M$. flabellifolia as a cultivated cassava. His provision of a new Latin diagnosis for $M$. esculenta subsp. flabellifolia, to serve a specific need of classification of the domesticate, proved unnecessary since Pohl's was a legitimately published species. This detail, however, shows that Ciferri conceived this species as domesticated stock, which is not the case.

\section{The taxonomy of cassava}

Croizat (1943b) regarded $M$. aipi (sweet cassava) and $M$. digitiformis as belonging to the same species and actually they do. The latter stands for prevalently glabrous wild populations of the indigen. In the same paper, Croizat rightly voiced the view that Pax's (1910) circumscription of $M$. dulcis (sweet cassava) had become so confused as to turn the name of little utility. The present author holds the same view as to Mueller's (1874) mosaic treatment of the name $M$. palmata and, accordingly, sunk both epithets from the taxonomy of cassava.

An abbreviated taxonomic account of cassava follows. Only types seen by the author are cited here although there is more type material. A complete checklist of isotypes and syntypes is found in Rogers \& Appan's (1973) work which provides a complete taxonomic treatment of the cultigen, including erstwhile species. The acronym of the herbarium followed by a dash and a number (e.g. W-2) means the present author saw two isosyntypes placed in that particular herbarium.

\section{Key to the infraspecific units of cassava}

A. Plants under cultivation, entirely glabrous or hairs restricted to branches and/or leaves 1 . $M$. esculenta subsp. esculenta

AA. Plants growing wild.

b. Plants wholly glabrous or hairs restricted to branches and/or leaves 2. M. esculenta subsp. flabellifolia (Figs. 4, 5)

bb. Plants pubescent on branches, leaves, floral bracts, flowers, and fruits; vestiture becoming caducous both in mature vegetative parts and ripening fruits

3. M. esculenta
1. Manihot esculenta Crantz subsp. esculenta, Institutiones Rei Herbariae; nutum naturae digestae ex habitu 1: 167. 1766; Pax in Engler, Das Pflanzenreich IV. 147. 44: 67. 1910; Ciferri, Relaz. e Mon. AgrarioColoniali 44: 1-59. 1938; Archiv. Bot. Forli 18: 27-35. 1942; Croizat, Rev. Arg. Agron. 10: 214. 1943; Rogers \& Fleming, Econ. Bot. 27: 5. 1973; Rogers \& Appan, Fl. Neotr. 13: 25. 1973.

TYPE: Plates 4 and 5 in Merian's (1705) "Metamorphosis Insectorum Surinamensium". Synonyms: Manihot aipi Pohl, Pl. Bras. Ic. et Descr. 1: 29. 1827. Type: Pohl 3777 (W).

Manihot aipi var. lutescens Pohl, Pl. Bras. Ic. et Descr. 1: 31. 1827. Type: Pohl 3780 (W).

Manihot aipi var. lanceolata Pohl, Pl. Bras. Ic. et Descr. 1: 31. 1827. Type: Pohl 3778 (W-3).

Manihot aipi var. latifolia Pohl, Pl. Bras. Ic. et Descr. 1: 31. 1827. Type: Pohl 3776 (W).

Manihot utilissima Pohl, Pl. Bras. Ic. et Descr. 1: 32. t. 24. 1827. Type: Pohl 3775 (W) (Pohl 1712 also present on the sheet).

Manihot utilissima var. sutinga Pohl, Pl. Bras. Ic. et Descr. 1: 34. 1827. Type: Pohl 3781 (W).

Manihot utilissima var. castellana Pohl, Pl. Bras. Ic. et Descr. 1: 34. 1827. Type Pohl 3781 (W).

Manihot diffusa Pohl, Pl. Bras. Ic. et Descr. 1: 55. 1827. pro syn. Type: Martius s.n. (not seen).

Manihot loureirii Pohl, Pl. Bras. Ic. et Descr. 1: 55. 1827. pro syn. Type: Loureiro s.n. (not seen). Manihot flexuosa Pax \& Hoffm. in Engler, Das Pflanzenreich IV. 147. 85: 195. 1924. Type: Luetzelburg 9A (S).

Manihot esculenta subsp. grandifolia Ciferri, Arch.

Bot. Forli 18: 31. 1942.

In reducing $M$. flexuosa to the synonymy of $M$. esculenta the author followed Rogers and Appan (1973). M. flexuosa, as it stands, may be many things, including $M$. glaziovii Muell. Arg. The type has only leaves, which precludes a definitive judgement.

2. Manihot esculenta Crantz subsp. flabellifolia (Pohl) Ciferri, Arch. Bot. Forli 18: 31. 1942.

TYPE: Brazil. State of Goiás: municipality of Jaraguá, February 1819, Pohl 1188 (W-2).

Basionym: Manihot flabellifolia Pohl, PI. Bras. Ic. et Descr. 1: 35. t. 25.1827.

Synonyms: Manihot digitiformis Pohl, Pl. Bras. Ic. et Descr. 1: 36. t. 27. 1827.

Type: Pohl 1371 (W-2) (Pohl 1709 also appears on the sheet). 


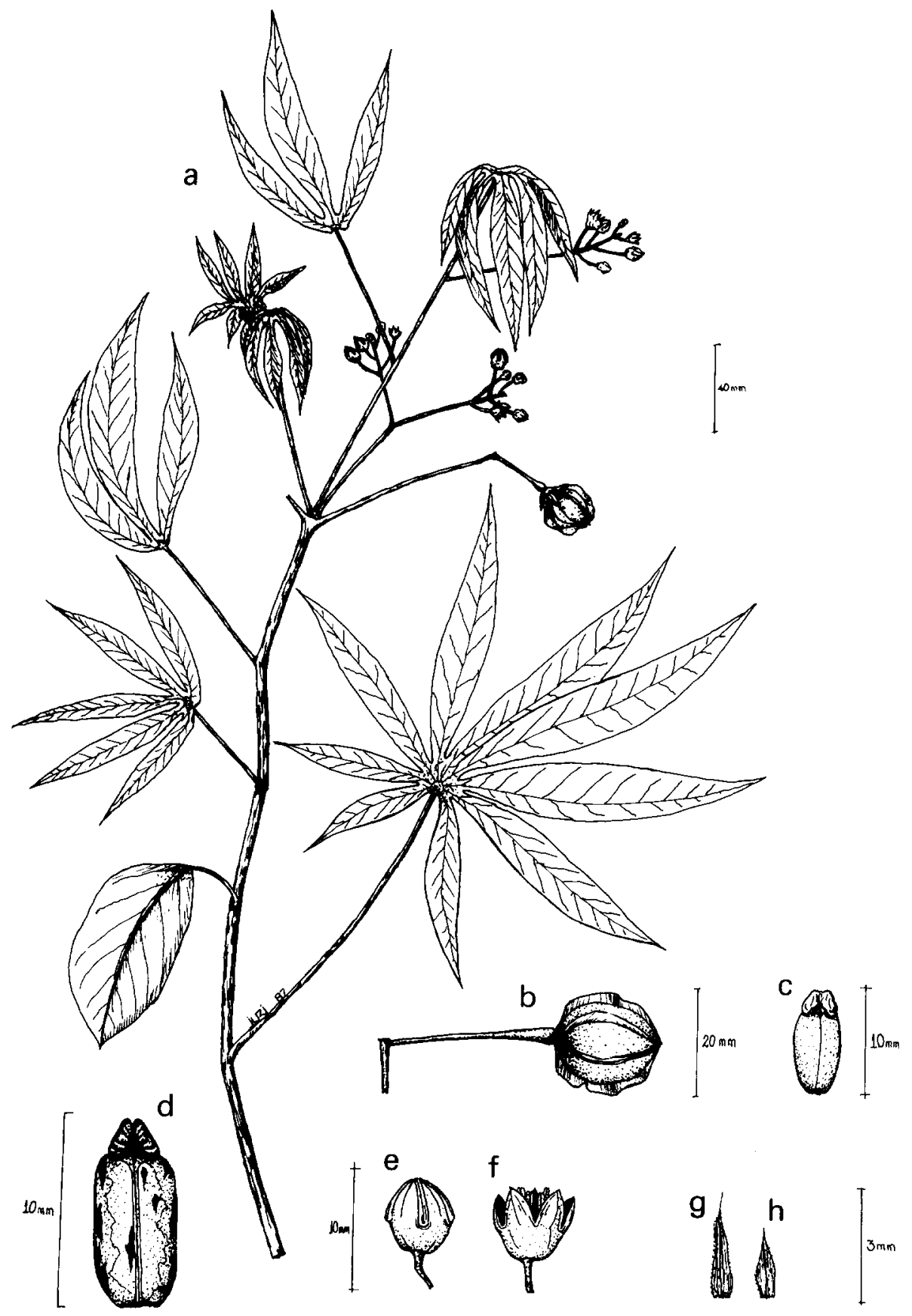

Fig. 4. Manihot esculenta subsp. flabellifolia (Allem \& Werneck 3419). a-upper floriferous branch, b ripe winged fruit, c-unripe seed, d-ripe seed, e-male bud, $\mathrm{f}$-male flower, $\mathrm{g}$-bract of male flower, $\mathrm{h}$-bracteole of male flower.

Manihot melanobasis Muell. Arg., Linnaea 34: 206. 1865. Type: Schomburgk 694 (K, P); Schomburgk 426 (W-2).

Manihot tristis Muell. Arg. in Martius, Fl. Bras.
11(2): 449. 1874. Type: Spruce 3604 (W, U, G, P, K). Manihot marajoara Chermonte de Miranda ex Huber, Bol. Mus. Paraense Hist. Nat. 5: 120. 1908. Type: Huber 2792 (RB). 


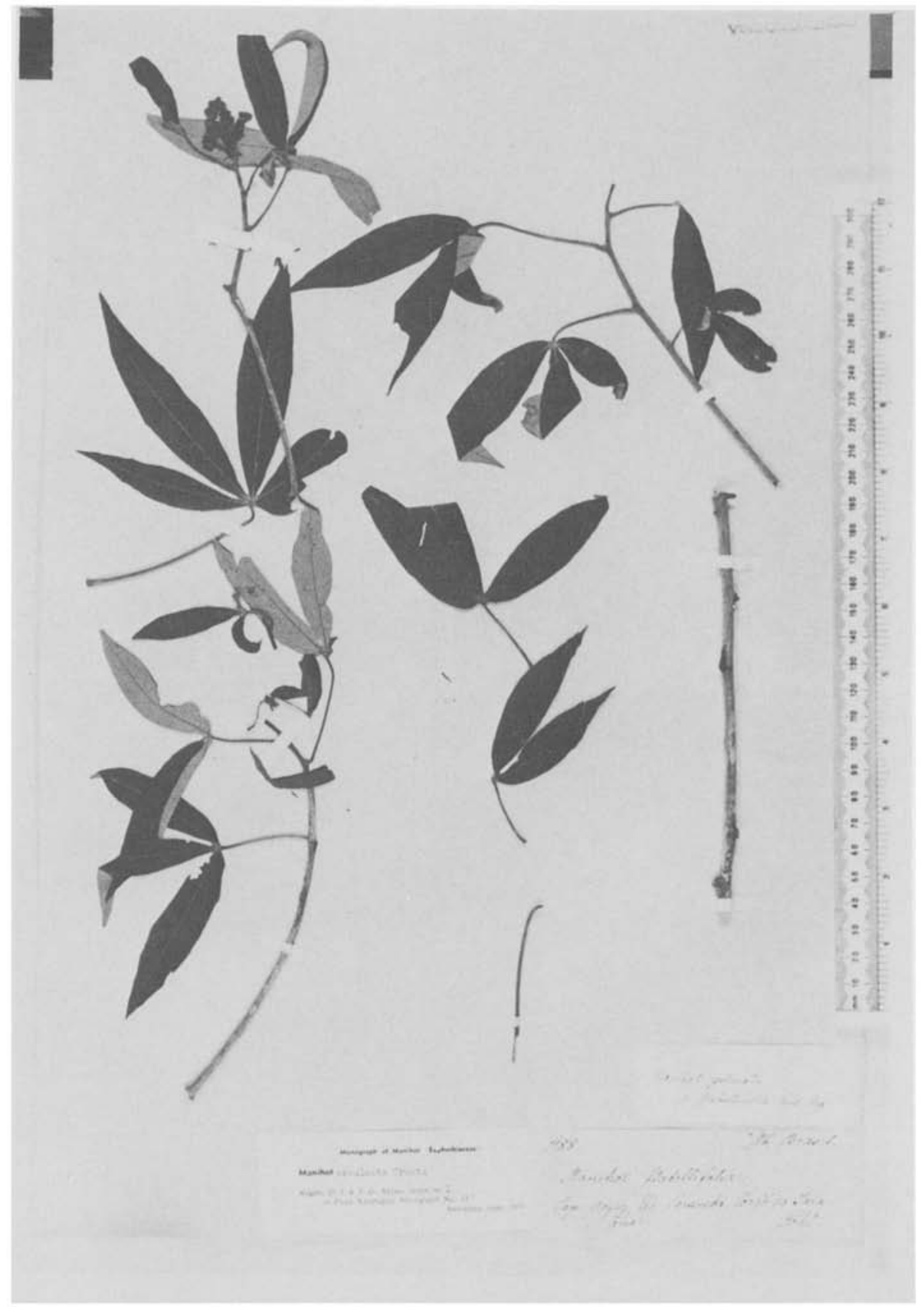

Fig. 5. Isosyntype of Manihot flabellifolia (Pohl 1188, W).

Manihot sprucei Pax in Engler, Das Pflanzenreich IV. 147. 44:71. 1910; M. esculenta var. Sprucei (Pax) Lanj., Euphorb. Surinam 33: 159. 1931. Type: Spruce 825 (U, P, K).

Manihot saxicola Lanjouw, Meded. Bot. Mus. Herb. Rijksuniv. Utrecht 69:544. 1939; Recueil
Trav. Bot. Neerl. 36: 544. 1939; M. tristis subsp. saxicola (Lanj.) Rogers \& Appan, Fl. Neotr. 13: 84. 1973. Type: Lanjouw 955 (U-3).

Manihot orinocensis Croizat, J. Arnold Arb. 24: 169. 1943. Type: Williams 13132 (S). 


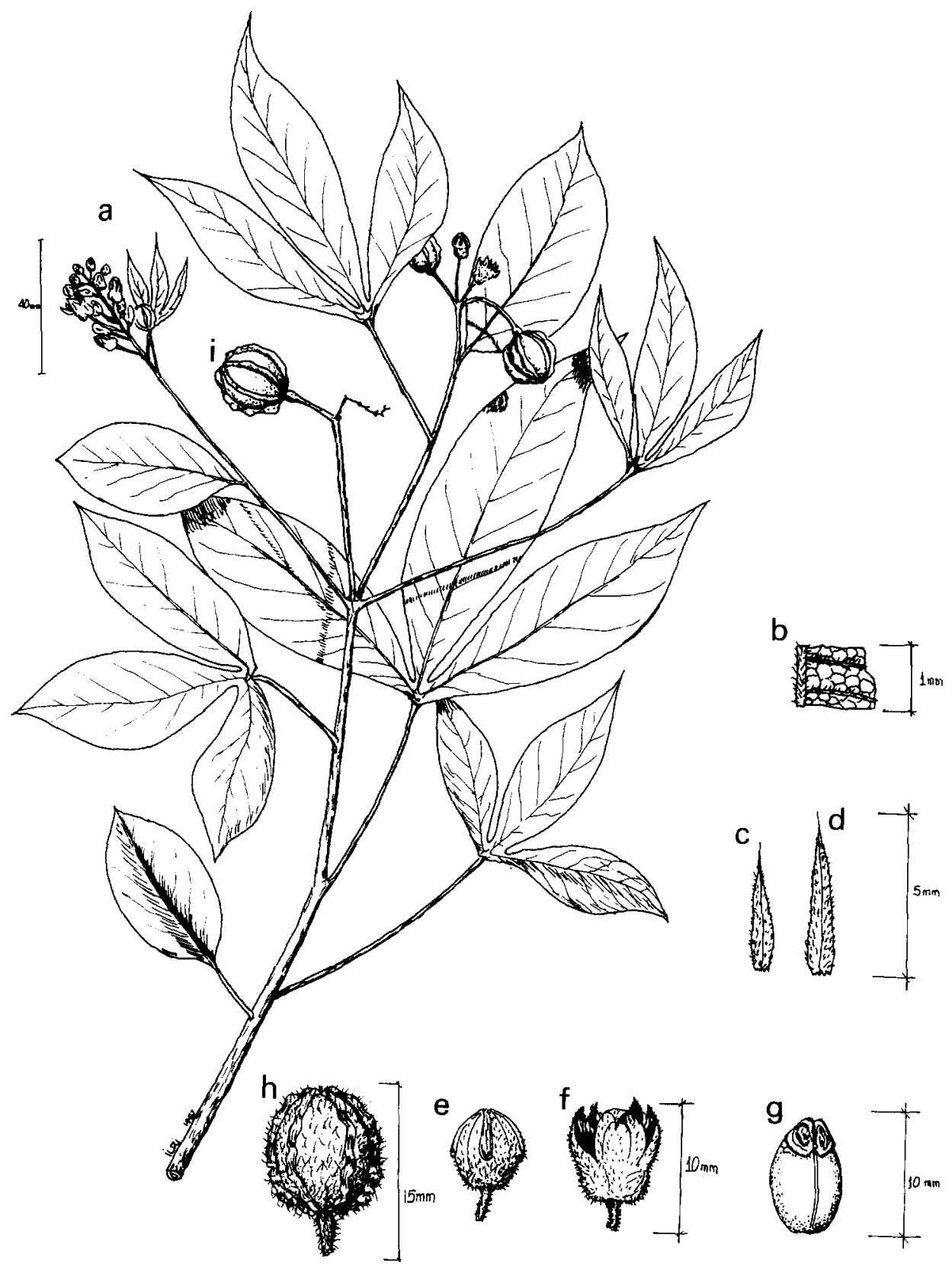

Fig. 6. Manihot esculenta subsp. peruviana (all illustrations from Allem \& Werneck 3531 except h from Allem \& Werneck 3568). a-upper floriferous branch, b-detail of the abaxial side of the leaf depicting the vestiture, c-bracteole of male flower, $d-b r a c t$ of male flower, e-male bud, $\mathrm{f}$-male flower, $\mathrm{g}$-nearly ripe seed, $\mathrm{h}$-ripe pubescent fruit, $\mathrm{i}$-glabrous fruit; the hairs are caducous with age.

Manihot surinamensis Rogers \& Appan, F1. Neotr. 13: 80. 1973. Type: Rombouts 464 (U).

3. Manihot esculenta Crantz subsp. peruviana (Muell. Arg.) Allem, stat. nov. TYPE: Peru.
Department San Martin: by Tarapoto, October 1855, Spruce 4287 (P). Basionym: Manihot peruviana Muell. Arg., Linnaea 34: 206. 1865. 
Synonyms: Manihot surumuensis Ule, Bot. Jahrb. Syst. 114: 12. 1914; $M$. tristis subsp. surumuensis (Ule) Rogers \& Appan, Fl. Neotr. 13: 86. 1973. Type: Ule 7944 (MG).

\section{Acknowledgements}

The study was partly sponsored by the International Board for Plant Genetic Resources (FAO/IBPGR) by financing cassava germplasm collecting field missions in 1986, 1992 and 1993. Iuri Cozac made the line drawings of Manihot species. Clélia Raquel Gasparotti typed the manuscript. Sérgio Eustáquio de Noronha made the maps. One of the reviewers improved substantially the readability of the text.

\section{References}

Allem, A. C., 1987. Manihot esculenta is a native of the Neotropics. Pl. Genet. Res. Newslett. 71: 22-24.

Allem, A. C., 1992. Manihot germplasm collecting priorities. Paper delivered at the international workshop on cassava genetic resources, CIAT, Cali, Colombia, 18-23 August, 1992. CIAT/IITA/IBPGR.

Baker, H. G., 1970. Taxonomy and the biological species concept in cultivated plants. In: O. H. Frankel \& E. Bennett (Eds.), Genetic Resources in Plants-Their Exploration and Conservation, pp. 49-68, IBP Handbook 11, Blackwell, Oxford.

Baker, H. G., 1971. Commentary: section 3. In: C. L. Riley, J. C. Kelley, C. W. Pennington \& R. L. Rands (Eds.), Man Across the Sea: Problems of Pre-Columbian Contacts, pp. 428-444, University of Texas Press, Austin.

Beadle, G. W., 1977. The origin of zea mays. In: C. A. Reed (Ed.), Origins of Agriculture, pp.615-635, Mouton, The Hague.

Bolhuis, G. G., 1953. A survey of some attempts to breed cassava varieties with a high content of protein in the roots. Euphytica 2: 107-112.

Bolhuis, G. G., 1967. Intra and interspecific cross in the genus Manihot. pp. 81-88 in Proc. First Intern. Symp. Tropical Root Crops. Trinidad, West Indies.

Bretting, P. K., 1990. New perspectives on the origin and evolution of New World domesticated plants: introduction. Econ. Bot. 44(3S): 1-5.

Ciferri, R., 1938. Saggio di classificazione delle razze di manioca (Manihot esculenta Crantz). Relazioni e Monografie Agrario Coloniali n. 44. 59p. Firenze.

Ciferri, R., 1942. Fondamenti per una classificazione subspecifica della Manihot esculenta Crantz. Archiv. Bot. Forli 18: 27-35.

Coursey, D. G. \& R. H. Booth, 1977. Root and tuber crops. In: C. L. A. Leakey \& Wills J. B. (Eds.), Food Crops of the Lowland Tropics, pp. 75-96, Oxford University Press, Oxford.

Crantz, H., 1766. Institutiones Rei Herbarie. Nutum Naturae Digestae ex Habitu. Vol. 1. Impensis Joannis Pauli Kraus. Vindobonae (Vienna)

Croizat, L., 1943a. Novelties in American Euphorbiaceae. J. Arn. Arb. 24: 165-189.

Croizat, L., 1943b. Preliminari per uno studio del genere Manihot nell' America meridionale. Rev. Arg. Agron. 10: 213-226.

Gentry, H. S., 1969. Origin of the common bean, Phaseolus vulgaris. Econ. Bot. 23: 55-69.

Gregory, W. C., A. Krapovickas \& M. P. Gregory, 1980. Structure, variation, evolution and classification in Arachis. In: R. J. Summerfield \& A. H. Bunting (Eds.), Advances in Legume science. Vol. 1 of the Proceedings of the International Legume Conference, pp. 469-481, Royal Botanic Gardens, Kew.

Hawkes, J. G., 1979. Evolution and polyploidy in potato species. In: J. G. Hawkes, R. N. Lester \& A. D. Skelding (Eds.), The Biology and Taxonomy of the Solanaceae, pp. 637-645, Linnean Society Symposium Series. n. 7. Academic Press, London.

Heiser, Jr. C. B., 1979. Origins of some cultivated New World plants. Annual Rev. Ecol. Syst. 10: 309-326.

Heiser, Jr. C. B., 1990. New perspectives on the origin and evolution of New World domesticated plants: summary. Econ. Bot. 4(3S): 111-116.

Holmgren, P. K., N. H. Holmgren \& L. C. Barnett, 1990. Index Herbariorum, 8th ed., Regnum Vegetabile Vol. 120. New York Botanical Garden, New York.

Holst, B. K. \& C. A. Todzia, 1990. Léon Croizat's plant collections from the Franco-Venezuelan expedition to the headwaters of the rio Orinoco. Ann. Missouri Bot. Gard. 77: 485-516.

Jennings, D. L., 1959. Manihot melanobasis Muell. Arg.-a useful parent for cassava breeding. Euphytica 8: 157-162.

Jennings, D. L., 1963. Variation in pollen and ovule fertility in varieties of cassava, and the effect of interspecific crossing on fertility. Euphytica 12: 69-76.

Jennings, D. L., 1979. Cassava. In: N. W. Simmonds (Ed.), Evolution of Crop Plants, pp. 81-84, Longman, London.

Kaplan, L., 1971. Phaseolus: Diffusion and centers of origin. In: C. L. Riley, J. C. Kelley, C. W. Pennington \& R. L. Rands (Eds.), Man Across the Sea: Problems of Pre-Columbian Contacts, pp. 416-427, University of Texas Press, Austin.

Lanjouw, J., 1932. Euphorbiaceae. pp. 1-101 A. Pulle (Ed), Flora of Surinam. Vol. II. Part 1. Kon. ver. Koloniaal Instituut te Amsterdam. Amsterdam.

Lanjouw, J., 1935. Additions to Pulle's flora of Surinam. Rec. Trav. Bot. Néerl. 32: 215-278.

Lanjouw, J., 1939. Two interesting species of Manihot L. from Suriname. Rec. Trav. Bot. Néerl. 36: 543-549.

León, J., 1977. Origin, evolution, and early dispersal of root and tuber crops. In: J. Cock, R. Macintyre \& M. Graham (Eds.), Proceedings 4th Symposium International Society Tropical Root Crops, pp. 20-36, International Development Research Centre, Ottawa.

Linnaeus, C., 1753. Species Plantarum. Vol. II. Facsimile of the first edition by the Ray Society, London. 
Linnaeus, C., 1771. Mantissa Plantarum Altera. Facsimile by J. Cramer, Weinheim.

Merian, M. S., 1705. Metamorphosis Insectorum Surinamensium. Pls. 1-60. Dutch edition. Amsterdam.

Miller, P., 1754. The Gardener's Dictionary, 4th ed. Vol. II. London.

Mueller Aargau, J., 1865. Euphorbiaceae. Vorläufige Mittheilungen aus dem für De Candolle's Prodromus bestimmten Manuscript über diese Familie. Linnaea 34: 1-224.

Mueller Aargau, J., 1866. Euphorbiaceae. In: A. de Candolle (Editor), Prodromus 15(2): $189-1261$.

Mueller Aargau, J., 1874. Euphorbiaceae. C. F. P. von Martius (Editor), Flora Brasiliensis 11(2): 293-750. Pls. 43-104.

Nichols, R. F. W., 1947. Breeding cassava for virus resistance. East Afr. Agric. J. 13: 184-194.

Pax, F., 1910. Euphorbiaceae-Adrianeae. In: A. Engler (Editor), Das Pflanzenreich IV. 147. II. 44: 1-111.

Pax, F., 1914. Euphorbiaceae-Additamentum V. In: A. Engler (Editor), Das Pflanzenreich IV. 147. VII. 63: 401-402.

Pickersgill, B., 1977. Taxonomy and the origin and evolution of cultivated plants in the New World. Nature 268: 591-595.

Pickersgill, B. \& C. B. Heiser Jr., 1977. Origins and distribution of plants domesticated in the New World tropics. In: C. A. Reed (Ed.), Origins of Agriculture, pp. 803-835, Mouton, The Hague.

Pohl, J. E., 1827. Plantarum Brasiliae Icones et Descriptiones. 1: 1-136. Pls. 1-100. Vindobonae. (Manihot 17-56; pls. 10 48).

Renvoize, B. S., 1972. The area of origin of Manihot esculenta as a crop plant-a review of the evidence. Econ. Bot. 26: 352-360.

Rogers, D. J., 1963. Studies of Manihot esculenta Crantz and related species. Bull. Torrey Bot. Club 90: 43-54.

Rogers, D. J., 1965. Some botanical and ethnological considerations of Manihot esculenta. Econ. Bot. 19: 369-377.

Rogers, D. J., 1972. Some further considerations on the origin of $M$. esculenta. Trop. Root Tuber Crops Newslett. 6: 4-10.

Rogers, D. J. \& S. G. Appan, 1973. Manihot and Manihotoides (Euphorbiaceae). A computer-assisted study. Flora Neotropica, Monograph n. 13. Hafner Press, New York.

Rogers, D. J. \& H. S. Fleming, 1973. A monograph of Manihot esculenta with an explanation of the taximetrics methods used. Econ. Bot. 27: 1-113.

Smith, Jr. C. E., 1968. The New World centers of origin of cultivated plants and the archaeological evidence. Econ. Bot. 22: 253-266.

Smith, Jr. C. E., 1977. Recent evidence in support of the tropical origin of New World crops. In: D. S. Seigler (Ed.), Crop Resources, pp. 79-95, Academic Press, New York.

Stafleu, F. A. \& R. S. Cowan, 1983. Taxonomic Literature, 2nd. ed. Vol. IV: P-Sak. Regnum Vegetabile Vol. 110. W. Junk, The Hague.

Stearn, W. T., 1982. Maria Sibylla Merian (1647-1717) as a botanical artist. Taxon 31: 529-534.

\section{Appendix 1}

Current distribution of Manihot esculenta subsp. flabellifolia in Brazil. See Fig. 1.
GOIÁS: km 200 GO-060 highway São Luís de Montes BelosIporá (16 22 S 5102 W), 9 Mar. 1982, Allem et al. 2794 (CEN); $16 \mathrm{~km}$ NE of Iporá (16 $30 \mathrm{~S} 5100 \mathrm{~W}$ ), $25 \mathrm{Feb}$. 1986, Allem 3401 (CEN, NA, NY); $19 \mathrm{~km}$ NE of Iporá (16 30 S 5053 W), $25 \mathrm{Feb}$. 1986, Allem 3406 (CEN, NA); $38 \mathrm{~km}$ NE of Iporá (16 30 S 5045 W), 25 Feb. 1986, Allem 3407 (CEN, NA, MO); $40 \mathrm{~km}$ NE of Iporá (16 30S $5043 \mathrm{~W}$ ), 25 Feb. 1986, Allem 3408 (CEN); $70 \mathrm{~km} \mathrm{NE}$ of Iporá (1630 S $5045 \mathrm{~W}$ ), 25 Feb. 1986, Allem 3409 (CEN); $81 \mathrm{~km} \mathrm{NE}$ of Iporá (16 $33 \mathrm{~S} 5030 \mathrm{~W}), 25$ Feb. 1986, Allem 3410 (CEN, NA); Iporá, 26 Feb. 1986, Allem 3419 (CEN, NA, K, P, G); Iporá, 26 Feb. 1986, Allem 3420 (CEN, NA, MO, NY); Iporá, 26 Feb. 1986, Allem 3421 (CEN, NA, K, P); $16 \mathrm{~km}$ SE of Nazário (16 35 S $4945 \mathrm{~W}$ ), 26 Feb. 1986, Allem 3424 (CEN, NA, G); 5 km NE of Rui Barbosa (16 38 S $4949 \mathrm{~W}$ ), 26 Feb. 1986, Allem 3427 (CEN, NA); $8 \mathrm{~km} \mathrm{SW}$ of Goiás Velho (15 50 S $5015 \mathrm{~W}$ ), 27 Feb. 1986, Allem 3428 (CEN, NA); Goiás Velho, 27 Feb. 1986, Allem 3429 (CEN, NA, NY); $20 \mathrm{~km}$ SE of Itaberaí (I 608 S 4942 W), 27 Feb. 1986, Allem 3432 (CEN, NY); Itaberai, 27 Feb. 1986, Allem 3434 (CEN, MO, K, P); 9 km SE of Itauçu (1608 S 49 45 W), 27 Feb. 1986, Allem 3435 (CEN, NY, G); $4 \mathrm{~km}$ NE of Goiânia (1628 S $4910 \mathrm{~W}$ ), 27 Feb. 1986, Allem 3436 (CEN, NY, G); Goiânia, 27 Feb. 1986, Allem 3437 (CEN, MO, NY); Goiânia, 27 Feb. 1986, Allem 3438 (CEN, K, P, G); Goiânia, 27 Feb. 1986, Allem 3440 (CEN, NY); $25 \mathrm{~km} \mathrm{NE}$ of Corumbá de Goiás (15 $45 \mathrm{~S} 4845 \mathrm{~W}$ ), 28 Feb. 1986, Allem 3444 (CEN, MO, NY, K); $32 \mathrm{~km} \mathrm{NE}$ of Corumbá de Goiás (15 43 S 48 44W), 28 Feb. 1986, Allem 3445 (CEN, MO, K, P, G); 27 km NW of Anápolis (16 10 S $4905 \mathrm{~W}$ ), 02 Mar. 1986, Allem 3455 (CEN, MO, NY); $52 \mathrm{~km} \mathrm{SW}$ of Anápolis (15 55 S 49 15 W), 02 Mar. 1986, Allem 3456 (CEN, P, G); $81 \mathrm{~km} \mathrm{NE}$ of Ceres (1445 S $4915 \mathrm{~W}$ ), 03 Mar. 1986, Allem 3458 (CEN, NY, K); Ceres, 03 Mar. 1986, Allem 3459 (CEN, P, G); $11 \mathrm{~km}$ E of Uruaçu (14 $30 \mathrm{~S} 4900 \mathrm{~W}$ ), 03 Mar. 1986, Allem 3460 (CEN, MO, NY, K); $300 \mathrm{~m}$ NE of Niquelândia $(1423 \mathrm{~S} 4830 \mathrm{~W}), 04$ Mar. 1986, Allem 3467 (CEN, MO, NY, K); $24 \mathrm{~km}$ NE of Niquelândia (14 16 S 4823 W), 04 Mar. 1986, Allem 3468 (CEN, NY, P, G); $42 \mathrm{~km} \mathrm{NE}$ of Niquelândia (14 15 S $4815 \mathrm{~W}$ ), 04 Mar. 1986, Allem 3469 (CEN, MO, NY, K); Anápolis, 19 Mar. 1986, Allem 3502, Allem 3504, Allem 3506 (CEN, NA, NY); $16 \mathrm{~km}$ NE of Paraiso do Norte (1003 S 4850 W), 27 May 1986, Allem 3610 (CEN, NA, NY, P); $25 \mathrm{~km}$ SE of Paraíso do Norte (1023 S $4853 \mathrm{~W}$ ), 27 May 1986, Allem 3613 (CEN, NA, NY, G); $62 \mathrm{~km}$ SE of Paraiso do Norte (10 $44 \mathrm{~S} 4855 \mathrm{~W}$ ), 27 May 1986, Allem 3614 (CEN, NA, K); $53 \mathrm{~km}$ SE of Porangatu (13 55 S 49 05 W), 28 May 1986, Allem 3615 (CEN, NA, MO, NY); Anápolis, 23 Oct. 1986, Allem 3623 (CEN, NY); Corumbá de Goiás, 09 Dec. 1986, Allem 3643 (CEN, MO, NY, K, P, G); Corumbá de Goiás, 09 Dec. 1986, Allem 3644 (CEN); $15 \mathrm{~km} \mathrm{NW}$ of Corumbá de Goiâs (1550 S $4900 \mathrm{~W}$ ), 09 Dec. 1986, Allem 3647 (CEN); $44 \mathrm{~km} \mathrm{NW}$ of Anápolis (16 35 S $4910 \mathrm{~W}$ ), 21 May 1992, Allem 3986 (CEN); district of Hinterlândia by Anápolis (16 15 S 4904 W), 16 May 1992, Allem 4047 (CEN); $13 \mathrm{~km} \mathrm{~N}$ of Guaraí (08 $45 \mathrm{~S} 4835 \mathrm{~W}$ ), 08 Mar. 1992, Valls et al. 6550 (CEN).

MATO GROSSO: $16 \mathrm{~km}$ SE of Rondonópolis (1635 S $5430 \mathrm{~W}$ ), 08 May 1986, Allem 3515 (CEN, NA); $43 \mathrm{~km} \mathrm{NW}$ of Rondonópolis (1608 S $5450 \mathrm{~W}$ ), 09 May 1986, Allem 3516 (CEN, NA, NY); $4 \mathrm{~km} \mathrm{NW}$ of Jaciara $(1558 \mathrm{~S} 5500 \mathrm{~W})$, 
09 May 1986, Allem 3517 (CEN, NA, MO, K); $70 \mathrm{~km}$ NW of Jaciara (15 48 S $5535 \mathrm{~W}$ ), 09 May 1986, Allem 3518 (CEN, NA, G); Jaciara, 09 May 1986, Allem 3519 (CEN, NA, DAV, K, P); $163 \mathrm{~km} \mathrm{NW}$ of Cáceres (1538 S 5848 W), 11 May 1986, Allem 3525 (CEN); $210 \mathrm{~km} \mathrm{NW}$ of Cáceres (15 17 S 59 16 W), 12 May 1986, Allem 3530 (CEN, P, G); Pontes e Lacerda, 12 May 1986, Allem 3532 (CEN, NA); $94 \mathrm{~km}$ NW of Pontes e Lacerda (14 26 S 4930 W), 12 May 1986, Allem 3533 (CEN, NA, K, P, G); $161 \mathrm{~km}$ SE of Vilhena on road to Cáceres (1406 S 5942 W), 19 May 1986, Allem 3573 (CEN, NA, NY); $265 \mathrm{~km}$ SE of Vilhena (1500 S $5925 \mathrm{~W}), 19$ May 1986, Allem 3574 (CEN, NA, MO, K); $29 \mathrm{~km}$ NE of Serra Dourada (1326 S $5200 \mathrm{~W}), 24$ May 1986, Allem 3598 (CEN, MO, NY, K); $118 \mathrm{~km}$ NE of Porto Alegre (0958 S $5100 \mathrm{~W}$ ), 26 May 1986, Allem 3605 (CEN, NA, MO, NY, K); $14 \mathrm{~km}$ NE of Vila Rica (09 46 S 5109 W), 26 May 1986, Allem 3606 (CEN, NA, NY, P, G); Fazenda Estrela do Guaporé, aldeia Alantesu (14 09 S 5947 W), Vila Bela, 27 May 1985, Valls \& Silva 8886 (CEN); $12 \mathrm{~km}$ SE of Lambari (15 25 S $5756 \mathrm{~W}$ ), 23 May 1992, Allem 3987 (CEN); $100 \mathrm{~km} \mathrm{NW}$ of Pontes e Lacerda (14 21 S 5935 W), 25 May 1992, Allem 3993 (CEN); $156 \mathrm{~km} \mathrm{NW}$ of Pontes e lacerda (13 54 S 5944 W), 25 May 1992, Allem 3999 (CEN); $104 \mathrm{~km} \mathrm{NW}$ of Pontes e Lacerda (14 18 S 5939 W), 08 June 1992, Allem 4033 (CEN); 74 km NW of Jaciara, Sierra of Saint Vincent (15 40 S $5530 \mathrm{~W}$ ), 13 May 1992, Allem 4048 (CEN).

RONDÔNIA: $161 \mathrm{~km} \mathrm{NW}$ of Vilhena $(1150 \mathrm{~S} 6102 \mathrm{~W}), 13$ May 1986, Allem 3540 (CEN, NA, NY), Allem 3541 (CEN, NA, MO, K, P); $172 \mathrm{~km} \mathrm{NW}$ of Vilhena (11 $48 \mathrm{~S} 6104 \mathrm{~W}), 13$ May 1986, Allem 3542 (CEN, NA, NY, G); $6 \mathrm{~km} \mathrm{NW}$ of Pimenta Bueno (1138 S61 11 W), 13 May 1986, Allem 3543 (CEN, NA, MO, K); Pimenta Bueno, 13 May 1986, Allem 3544 (CEN, NA, NY); $32 \mathrm{~km} \mathrm{NW}$ of Pimenta Bueno (1129 S $6122 \mathrm{~W}$ ), 14 May 1986, Allem 3545 (CEN, NA, MO, K); 4 km NE of Riozinho (11 28 S 6121 W), 14 May 1986, Allem 3546 (CEN, NA, K, P); Riozinho, 14 May 1986, Allem 3547 (CEN, NA, G); $26 \mathrm{~km} \mathrm{NW}$ of Cacoal (11 26 S $6135 \mathrm{~W}), 15$ May 1986, Allem 3553 (CEN, NA, DAV, NY); 51 km NW of Cacoal (1121 S $6151 \mathrm{~W}$ ), 15 May 1986, Allem 3554 (CEN, NA, MO, K); $25 \mathrm{~km} \mathrm{NW}$ of Ouro Preto do Oeste (1034 S $6222 \mathrm{~W}$ ), 15 May 1986, Allem 3558 (CEN, NA, NY); $6 \mathrm{~km} \mathrm{NW}$ of Jaru (10 26 S $6230 \mathrm{~W}$ ), 15 May 1986, Allem 3559 (CEN, NA, K, G); $17 \mathrm{~km} \mathrm{NW}$ of Ariquemes (0947 S6305 W), 16 May 1986, Allem 3560 (CEN, NA, P); Ariquemes, 16 May 1986, Allem 3561 (CEN, NA, NY, K), Allem 3562 (CEN, NA, MO, G); $30 \mathrm{~km} \mathrm{NW}$ of Ariquemes (09 40S6305 W), 16 May 1986, Allem 3563 (CEN, NA, NY, K, P); $66 \mathrm{~km} \mathrm{NW}$ of Ariquemes (09 20 S63 08 W), I6 May 1986, Allem 3564 (CEN, NA, G); $150 \mathrm{~km} \mathrm{NW}$ of Vilhena (11 45 S $6105 \mathrm{~W}), 26$ May 1992, Allem 4000 (CEN); $40 \mathrm{~km} \mathrm{NW}$ of Ariquemes (09 $34 \mathrm{~S} 6305 \mathrm{~W}), 27$ May 1992, Allem 4008 (CEN); $92 \mathrm{~km} \mathrm{SW}$ of Porto Velho (09 16 S $6424 \mathrm{~W}$ ), 28 May 1992, Allem 4012 (CEN); $108 \mathrm{~km}$ SW of Porto Velho (09 $18 \mathrm{~S} 6433 \mathrm{~W}), 28$ May 1992, Allem 4014 (CEN); Vicinity of Fortaleza, rio Abunã (09 45 S 6530 W), 15 Nov. 1968, G. T. Prance, Rodrigues, Ramos \& Farias 8456 (MO); km 60-64 Guajará-Mirim-Abunã (10 15 S $6520 \mathrm{~W}), 01$ Feb. 1983, Carreira, Lisboa, Silva \& Rosário 486 (MO).

ACRE: $6,5 \mathrm{~km}$ NW of Rio Branco (0957 S $6753 \mathrm{~W}$ ), 01 June 1992, Allem 4019 (CEN); $27 \mathrm{~km} \mathrm{NW}$ of Rio Branco
(09 49 S 6758 W), 01 June 1992, Allem 4021 (CEN); $45 \mathrm{~km} \mathrm{NW}$ of Rio Branco (0944 S68 07 W), 01 June 1992, Allem 4022 (CEN); $5 \mathrm{~km} \mathrm{NE}$ of Rio Branco (0956 S $6748 \mathrm{~W}$ ), 02 June 1992, Allem 4023 (CEN); $52 \mathrm{~km} \mathrm{NE}$ of Rio Branco (09 38 S 6736 W), 02 June 1992, Allem 4024 (CEN); outskirts of Rio Branco (0958 S6748 W), 02 June 1992, Allem 4026 (CEN); $10 \mathrm{~km} \mathrm{SE}$ of Senador Guiomard (1005 S $6732 \mathrm{~W}), 02$ June 1992, Allem 4027 (CEN); $10 \mathrm{~km}$ after the crossroads with BR-364 highway along BR-317 highway bound for Boca do Acre (09 55 S 6733 W), 04 June 1992, Allem 4028 (CEN). AMAZONAS: Rio Negro, curso inferior, igapó (02 40 S6100 W), Michael Gouding 80 (MG).

$P A R \dot{A}$ : Serra do Cachimbo, BR-163 Cuiabá-Santarém highway km 807,5 (08 25 S 5520 W), G. T. Prance et al. 59704 (MG); Marabá, serra dos Carajás (06 00 S 5100 W), 14 Mar. 1984, Silva, Rosa, Bahia \& Santos 1793 (MO); Ilha de Marajó (01 00 S $5000 \mathrm{~W}$ ), 05 July 1902, Huber 2792 (MG, under the name $M$. marajoara).

$A M A P A \bar{A}:$ Quadrícula SB22 VA Ponto 44 (01 $00 \mathrm{~S} 5205 \mathrm{~W}), 09$ Apr. 1982, Rosa, Santos \& Silva 4219 (MO); Oiapoque river, Mt. Carupina (03 33 N 5137 W), 14 Oct. 1960, J. M. Pires \& L. Y. Th. Westra 48837 (IAN); Cachoeira de Santo Antonio, Região do rio Jari (00 40 S 5230 W), 06 Mar. 1969, N. T. Silva 1784 (IAN).

\section{Appendix 2}

Current distribution of the two wild subspecies of cassava in South America (except Brazil). See Fig. 2

Manihot esculenta subsp. fabellifolia. SURINAM: Mt. Voltzberg $(0500 \mathrm{~N} 5600 \mathrm{~W}), 23$ Sep. 1923, Lanjouw 955 (U, under the name $M$. saxicola); Coppename river (0500 N 5602 W), 9 Feb. 1965, Schulz \& Donselaar 10593 (U); Sipaliwini river ( 0500 N 5608 W), 9 Feb. 1936, Rombouts 464 (U, under the name $M$. surinamensis).

GUYANA: Rupununi savannas (0300 N $5900 \mathrm{~W})$, Aug. 1840 , Schomburgk 426 (W, under the name $M$. melanobasis). VENEZUELA: Orinoco river, Puerto Ayacucho $(0550 \mathrm{~N}$ $6740 \mathrm{~W}$ ), 27 May 1940, Williams 13132 (S, under the name $M$. orinocensis); Cerro Duida, rio Cunucunuma, Randal Pacure (03 20 N 6540 W), Estado Amazonas, 9 Nov. 1950, B. Maguire, R. S. Cowan \& J. J. Wurdack 29410 (US). BOLIVIA : Department La Paz, Prov. Iturralda, W del rio Beni, lado del rio Muqui (1300 S 6800 W), 24 Feb. 1984, Beck \& Haase 9985 (DAV).

Manihot esculenta subsp. peruviana. PERU: San Martin, Tarapoto (06 $30 \mathrm{~S} 7620 \mathrm{~W}$ ), Oct. 1855, Spruce 4287 (P).

\section{Appendix 3}

Current distribution of Manihot esculenta subsp. peruviana in Brazil. See Fig. 3

MATO GROSSO: $208 \mathrm{~km} \mathrm{NW}$ of Cáceres (15 $18 \mathrm{~S} 5914 \mathrm{~W}$ ), 11 May 1986, Allem 3527 (CEN, NA); Pontes e Lacerda, 11 May 1986, Allem 3528 (CEN, NA, MO, NY), Allem 3529 (CEN, NA, K); $210 \mathrm{~km} \mathrm{NW}$ of Cáceres (15 17 S $5916 \mathrm{~W}), 12$ 
May 1986, Allem 3531 (CEN, NA, MO, NY); $110 \mathrm{~km} \mathrm{NW}$ of Pontes e Lacerda (14 17 S 5938 W), 12 May 1986, Allem 3534 (CEN, NA, MO, NY); $140 \mathrm{~km} \mathrm{NW}$ of Pontes e Lacerda (14 05 S 5944 W), 12 May 1986, Allem 3535 (CEN, NA, K, P); Vila Bela da Santíssima Trindade, 12 May 1986, Allem 3536 (CEN, NA, NY, G); 15 km SE of Lambari (1526 S $5752 \mathrm{~W}$ ), 23 May 1992, Allem 3988 (CEN); $3 \mathrm{~km} \mathrm{NW}$ of Panorama (15 18 S $5802 \mathrm{~W}), 23$ May 1992, Allem 3989 (CEN); $207 \mathrm{~km} \mathrm{NW}$ of Pontes e Lacerda (1520 S $5912 \mathrm{~W}$ ), 24 May 1992, Allem 3990 (CEN); $117 \mathrm{~km} \mathrm{NW}$ of Pontes e Lacerda (14 12 S $5940 \mathrm{~W}$ ), 25 May 1992, Allem 3995 (CEN); $152 \mathrm{~km}$ NW of Pontes e Lacerda (13 52 S 5946 W), 08 June 1992, Allem 4031 (CEN); $12 \mathrm{~km} \mathrm{SE} \mathrm{of} \mathrm{Lambari} \mathrm{(1525} \mathrm{S} 5756 \mathrm{~W}$ ), 09 June 1992, Allem 4034 (CEN); $7 \mathrm{~km}$ SE of Salto do Céu (15 10 S $5806 \mathrm{~W}$ ), 10 June 1992, Allem 4036 (CEN); $15 \mathrm{~km} \mathrm{SE}$ of Lambari on road to São José do Pingador (1526 S 5752 W), 09 June 1992, Allem 4035 (CEN).
RONDÔNIA: $3 \mathrm{~km} \mathrm{SW}$ of Porto Velho (0848 S $6355 \mathrm{~W}$ ), 17 May 1986, Allem 3568 (CEN); $9 \mathrm{~km} \mathrm{SW}$ of Porto Velho (08 50 S 63 56 W), 17 May 1986, Allem 3570 (CEN, NA, MO, NY, K, P); $68 \mathrm{~km}$ NW of Ariquemes (09 $20 \mathrm{~S} 6308 \mathrm{~W}), 18$ May 1986, Allem 3571 (CEN, NA, MO, NY), Allem 3572 (CEN, NA, MO, NY); $30 \mathrm{~km} \mathrm{NW}$ of Cacoal (11 22 S $6142 \mathrm{~W}$ ), 26 May 1992, Allem 4004 (CEN); $20 \mathrm{~km}$ ahead of the Porto Velho-Abunã-Guajará-Mirim crossroads on road to GuajaráMirim (09 55 S 6518 W), 29 May 1992, Allem 4015 (CEN); $51 \mathrm{~km}$ ahead of the Porto Velho-Abunã-Guajará-Mirim crossroads on road to Guajará-Mirim (1011 S6517 W), 29 May 1992, Allem 4016 (CEN); $63 \mathrm{~km}$ ahead of the Porto Velho-Abunã-Guajará-Mirim crossroads on road to Guajará-Mirim (10 18 S65 17 W), 29 May 1992, Allem 4017 (CEN).

RORAIMA: Surumu savannas (04 10 N 6040 W), Feb. 1909 , Ule 7944 (MG, under the name $M$. surumuensis). 